\title{
Species of Pythium from Greenhouses in Pennsylvania Exhibit Resistance to Propamocarb and Mefenoxam
}

\author{
G. W. Moorman, Department of Plant Pathology, The Pennsylvania State University, University Park 16802-4506; \\ and S. H. Kim, Bureau of Plant Industry, Pennsylvania Department of Agriculture, Harrisburg 17110-9408
}

\begin{abstract}
Moorman, G. W., and Kim, S. H. 2004. Species of Pythium from greenhouses in Pennsylvania exhibit resistance to propamocarb and mefenoxam. Plant Dis. 88:630-632.

Pythium isolates from commercial greenhouses in Pennsylvania were tested in vitro and in vivo for sensitivity to propamocarb. Isolates of Pythium aphanidermatum, P. irregulare, and P. ultimum consistently infected geranium seedlings that had been treated with propamocarb. $P$. ultimum and $P$. irregulare isolates exhibited dual fungicide resistance by overcoming propamocarb, mefenoxam, and a mixture of propamocarb and mefenoxam to infect seedlings. The sensitivity of isolates to propamocarb in vitro was not a good predictor of in vivo sensitivity. This is the first report of Pythium spp. resistance to propamocarb and dual resistance to propamocarb and mefenoxam.
\end{abstract}

Species of Pythium often are associated with root, stem, and cutting rots as well as pre- and post-emergence damping-off of seedlings in greenhouse crops $(2-4,11)$. In addition to the commercial formulations of the biological control agents Trichoderma harzianum, Bacillus subtilis, Streptomyces griseoviridis, and Gliocladium virens, several fungicides belonging to different classes of chemicals $(1,10)$ are used to protect plants from Pythium spp., including azoxystrobin (strobilurin), fosetylaluminum (alkyl phosphonate), mefenoxam and metalaxyl (acylanilide), etridiazole (triadiazole), and propamocarb (carbamate). Resistance to the acylanilide fungicides has been found in Pythium spp. but resistance to other fungicides has not. Resistance to metalaxyl in North America was first reported in 1984 (8) when the chemical failed to prevent turf blight caused by $P$. aphanidermatum in Pennsylvania. More recently, $P$. ultimum populations with mefenoxam resistance were isolated from infected potato (9). The identity of Pythium isolates from Pennsylvania greenhouse crop, soil, and water samples and their sensitivity to mefenoxam was reported previously (5). The objective of this research was to examine the sensitivity

Corresponding author: G. W. Moorman E-mail: gmoorman@psu.edu

Generous funding of this project was provided by the American Floral Endowment, The Fred C. Gloeckner Foundation Inc., the Pennsylvania Floral Industry Association, and The Pennsylvania State University Agricultural Experiment Station.

Accepted for publication 20 January 2004.

Publication no. D-2004-0315-04R

(C) 2004 The American Phytopathological Society of Pythium isolates to propamocarb in vitro and to test the efficacy of propamocarb and a mixture of mefenoxam and propamocarb in protecting geranium seedling from infection by Pythium spp.

\section{MATERIALS AND METHODS}

Isolations. Pythium spp. were isolated from greenhouse crops, potting soil, and water samples submitted to the Penn State Plant Disease Clinic and the Pennsylvania Department of Agriculture, Bureau of Plant Industry by growers, county agents, and plant inspectors during 1996 to 2001, identified, and stored as previously reported (5).

Fungicide sensitivity in vitro. The sensitivity of isolates to propamocarb was tested on corn meal agar (CMA) amended with propamocarb at $0,1,10,100,1,000$, and $4,000 \mu \mathrm{g} / \mathrm{ml}$ by distributing Banol (66.5\% propamocarb; Aventis, Research Triangle Park, NC) into molten agar prior to pouring it into $100-\mathrm{mm}$ petri plates. Upon cooling, the plates were inoculated by inverting a 10-mm-diameter plug of colonized CMA onto the center of each plate. Two plates per fungicide concentration per isolate were incubated in the dark at $25^{\circ} \mathrm{C}$ for 18 to $24 \mathrm{~h}$. Growth was measured from the edge of the inoculum block to the edge of the colony along two random radii per plate and the average rate of growth per hour was calculated. Each isolate was tested at least twice. Isolate sensitivity to mefenoxam was reported previously (5).

Fungicide sensitivity in vivo. In vivo sensitivity screening was carried out with all Pythium isolates that grew on high concentrations of propamocarb in vitro and, as a comparison, with selected isolates that were inhibited by propamocarb in vitro $(P$. aphanidermatum, P18 and P23; P. irregu- lare, P73 and P75; P. ultimum, P17 and P19; P. dissotocum, 22017-97), all from the Pennsylvania isolate collection (5). The top or bottom of a $60-\mathrm{mm}$ petri plate was placed in a plastic container $100 \mathrm{~mm}$ in diameter and $45 \mathrm{~mm}$ deep to support a 9cm-diameter filter paper. Water-soluble fertilizer $(20 \mathrm{ml} ; \mathrm{N}$ at $400 \mu \mathrm{g} / \mathrm{ml} ; 20 \% \mathrm{~N}$, $20 \% \quad \mathrm{P}_{2} \mathrm{O}_{5}, 20 \% \quad \mathrm{~K}_{2} \mathrm{O}$ soluble fertilizer; Olympic Chemical Co., Mainland, PA) was added to each container to moisten the filter paper. Five geranium seeds (Pelargonium $\times$ hortorum $\mathrm{cv}$. 'White Orbit') were positioned on the filter paper. The containers were placed on a tray inside a clear plastic bag and incubated for 5 days in a lab $\left(22\right.$ to $\left.26^{\circ} \mathrm{C}\right)$ under fluorescent lights. Once the cotyledons were fully expanded and the first true leaf was just visible, 20 $\mathrm{ml}$ of the fertilizer solution amended with fungicide was used to replace the fertilizer solution in treatment containers. Propamocarb (Banol at $2.35 \mu \mathrm{l} / \mathrm{ml}$; equivalent to the label-recommended 3 fl. oz./10 gal concentration), mefenoxam (Subdue Maxx at $0.078 \mu \mathrm{l} / \mathrm{ml}$; equivalent to the labelrecommended rate of $1 \mathrm{fl}$. oz./100 gal concentration; Syngenta), or a mixture of propamocarb and mefenoxam at these concentrations was used. Two days after applying the fungicides, seedlings in one fungicide-free and one fungicide-treated container were inoculated by inverting one 10-mm-diameter plug of colonized potato dextrose agar onto the root of each seedling. Three days after inoculation, the number of seedlings that had collapsed or exhibited translucent or darkened roots or stems typical of Pythium infection was recorded. The experiment was repeated for each isolate on different dates. One isolate of $P$. irregulare (P25, which killed all inoculated seedlings in the absence of fungicide) was included in every experiment as an internal control. The mean and standard deviation of error of the number of seedlings infected were calculated.

\section{RESULTS}

Of the 120 Pythium isolates obtained from greenhouses, the in vitro growth of 19 isolates (Table 1) was not inhibited by $50 \%\left(\mathrm{EC}_{50}\right)$ by propamocarb at 1,000 $\mu \mathrm{g} / \mathrm{ml}$ compared with their growth on plates lacking propamocarb $\left(\mathrm{EC}_{50}>1,000\right.$ $\mu \mathrm{g} / \mathrm{ml})$. Where propamocarb at 1,000 $\mu \mathrm{g} / \mathrm{ml}$ did not inhibit growth by $50 \%$ or more, $4,000 \mu \mathrm{g} / \mathrm{ml}$ also had no effect (data not shown). Species exhibiting propamo- 
carb insensitivity in vitro included $P$. aphanidermatum, $P$. cylindrosporum, $P$. dissotocum, $P$. heterothallicum, $P$. irregulare, $P$. splendens, $P$. ultimum, and one isolate in the group F (filamentous sporangia; 11). The lowest concentration of propamocarb tested in culture $(1 \mu \mathrm{g} / \mathrm{ml})$ slightly stimulated the growth of some isolates (P16, 66011-99, 66012-99, 8119296, 42146-99, 63105-99, P75, 31036-96, P88, and P90). The growth of 62163-98, an isolate of $P$. aphanidermatum, was stimulated by propamocarb at $1,000 \mu \mathrm{g} / \mathrm{ml}$.

One isolate of $P$. aphanidermatum (P16), P. irregulare (P80), and P. ultimum (P88) each consistently infected most of the geranium seedlings that had been treated with propamocarb. These P. ultimum and $P$. irregulare isolates also overcame mefenoxam and a mixture of propamocarb and mefenoxam to infect seedlings. The growth response of an isolate to propamocarb in culture was not a reliable predictor of whether propamocarb would protect propamocarb-treated plants from that isolate. The $P$. aphanidermatum (P16) and P. ultimum (P88) isolates with $\mathrm{EC}_{50}$ s close to $1,000 \mu \mathrm{g} / \mathrm{ml}$ and the $P$. irregulare isolate $(\mathrm{P} 80)$ with an $\mathrm{EC}_{50}$ greater than $1,000 \mu \mathrm{g} / \mathrm{ml}$ killed many treated seedlings, whereas P25 ( $P$ irregulare), with an $\mathrm{EC}_{50}$ near $1,000 \mu \mathrm{g} / \mathrm{ml}$, and 81774-98, with an $\mathrm{EC}_{50}$ greater than $1,000 \mu \mathrm{g} / \mathrm{ml}$, did not infect a majority of propamocarb-treated plants.

There was considerable variation in success of seedling infection among the isolates tested (Table 1). The P. heterothallicum (22019-96) and two of the $P$. dissotocum isolates from Pennsylvania greenhouses were weakly pathogenic, usually killing fewer that three of the five inoculated seedlings. One $P$. dissotocum (22017-97) and the P. splendens (P69) isolates were shown to be nonpathogenic as tested here. Although several of the $P$. irregulare isolates were highly pathogenic, some (e.g., 63105-99 and 81273-97) were relatively weak pathogens.

\section{DISCUSSION}

Propamocarb was developed in the late 1970s for use against oomycetes (1). In vitro tests indicated that the $\mathrm{EC}_{50}$ of propamocarb ranged from 0.5 to $10 \mu \mathrm{g} / \mathrm{ml}$ for $P$. aphanidermatum, $P$. splendens, $P$. irregulare, $P$. ultimum, and $P$. arrhenomanes (6). Since that time, there have been no reports of resistance to propamocarb in oomycetes. Many isolates tested in this research had $\mathrm{EC}_{50} \mathrm{~s}$ of propamocarb close to or greater than $1,000 \mu \mathrm{g} / \mathrm{ml}$. It is not known whether this indicates that selection

Table 1. In vitro and in vivo sensitivity of Pythium isolates to mefenoxam and propamocarb fungicides

\begin{tabular}{|c|c|c|c|c|c|c|c|}
\hline \multirow[b]{2}{*}{ Isolate } & \multirow[b]{2}{*}{ Species } & \multirow[b]{2}{*}{ Sensitivity $^{\mathbf{b}}$} & \multirow[b]{2}{*}{ Growth $(\%)^{\mathrm{c}}$} & \multicolumn{4}{|c|}{ Mean number of geranium seedlings infected $\pm \mathrm{SD}^{\mathrm{a}}$} \\
\hline & & & & None $(\mathbf{N})^{\mathbf{d}}$ & Propamocarbe $^{\mathrm{e}}$ & Mefenoxam $^{f}$ & Prop + mefeng \\
\hline $\mathrm{P} 16$ & aphanidermatum & $\mathrm{S}$ & 50 & $5.0 \pm 0.0(2)$ & $4.5 \pm 0.7$ & $0.0 \pm 0.0$ & $0.5 \pm 0.7$ \\
\hline $62163-98$ & aphanidermatum & $\mathrm{S}$ & 136 & $3.8 \pm 2.5(4)$ & $1.5 \pm 1.9$ & $3.5 \pm 2.4$ & $1.5 \pm 2.4$ \\
\hline $66011-99$ & aphanidermatum & $\mathrm{R}$ & 100 & $4.3 \pm 1.6(6)$ & $2.7 \pm 2.3$ & $0.3 \pm 0.8$ & $0.0 \pm 0.0$ \\
\hline $66012-99$ & aphanidermatum & $\mathrm{S}$ & 80 & $4.2 \pm 1.6(6)$ & $1.2 \pm 2.0$ & $0.0 \pm 0.0$ & $0.3 \pm 0.8$ \\
\hline $81192-96$ & aphanidermatum & $\mathrm{R}$ & 100 & $3.3 \pm 2.9(2)$ & $0.0 \pm 0.0$ & $3.7 \pm 2.3$ & $1.3 \pm 2.3$ \\
\hline $\mathrm{P} 18^{\mathrm{h}}$ & aphanidermatum & $\mathrm{R}$ & 0 & $4.7 \pm 0.6$ & $1.7 \pm 2.9$ & $4.7 \pm 0.6$ & $2.0 \pm 2.6$ \\
\hline $\mathrm{P} 23^{\mathrm{h}}$ & aphanidermatum & $\mathrm{S}$ & 12 & $4.7 \pm 0.6$ & $1.3 \pm 2.3$ & $0.3 \pm 0.6$ & $0.0 \pm 0.0$ \\
\hline 54053-99 & cylindrosporum & $\mathrm{R}$ & 51 & $5.0 \pm 0.0$ & $3.3 \pm 2.4$ & $4.5 \pm 1.0$ & $3.8 \pm 1.5$ \\
\hline $62092-99$ & dissotocum & $\mathrm{S}$ & 60 & $3.2 \pm 2.2(5)$ & $0.0 \pm 0.0$ & $0.0 \pm 0.0$ & $0.2 \pm 0.4$ \\
\hline 72037-99 & dissotocum & $\mathrm{S}$ & 50 & $3.7 \pm 2.0(6)$ & $0.8 \pm 1.3$ & $0.2 \pm 0.4$ & $1.0 \pm 2.0$ \\
\hline $22017-97^{\mathrm{h}}$ & dissotocum & $\mathrm{S}$ & 50 & $0.0 \pm 0.0$ & $0.0 \pm 0.0$ & $0.0 \pm 0.0$ & $0.0 \pm 0.0$ \\
\hline P77 & group $f$ & $\mathrm{~S}$ & 60 & $4.2 \pm 1.3(5)$ & $0.6 \pm 0.9$ & $0.0 \pm 0.0$ & $0.0 \pm 0.0$ \\
\hline 22019-96 & heterothallicum & $\mathrm{R}$ & 70 & $2.3 \pm 2.1(4)$ & $0.0 \pm 0.0$ & $0.0 \pm 0.0$ & $0.0 \pm 0.0$ \\
\hline $\mathrm{P} 25$ & irregulare & $\mathrm{R}$ & 50 & $5.0 \pm 0.0(6)$ & $1.3 \pm 2.2$ & $4.8 \pm 0.4$ & $2.5 \pm 2.4$ \\
\hline $42146-99$ & irregulare & $\mathrm{R}$ & 80 & $3.2 \pm 2.5(5)$ & $2.2 \pm 1.8$ & $0.2 \pm 0.4$ & $0.2 \pm 0.4$ \\
\hline $45021-97$ & irregulare & $\mathrm{R}$ & 51 & $3.8 \pm 2.5(3)$ & $2.5 \pm 2.9$ & $3.8 \pm 2.5$ & $2.5 \pm 2.9$ \\
\hline 63105-99 & irregulare & $\mathrm{R}$ & 60 & $2.5 \pm 3.5(2)$ & $2.5 \pm 3.5$ & $2.5 \pm 3.5$ & $2.5 \pm 3.5$ \\
\hline 71002-99 & irregulare & $\mathrm{S}$ & 50 & $5.0 \pm 0.0$ & $3.7 \pm 2.3$ & $0.0 \pm 0.0$ & $0.0 \pm 0.0$ \\
\hline P72 & irregulare & $\mathrm{R}$ & 60 & $5.0 \pm 0.0$ & $4.0 \pm 1.4$ & $5.0 \pm 0.0$ & $4.0 \pm 1.4$ \\
\hline P80 & irregulare & $\mathrm{R}$ & 80 & $5.0 \pm 0.0(2)$ & $5.0 \pm 0.0$ & $5.0 \pm 0.0$ & $5.0 \pm 0.0$ \\
\hline $81273-97$ & irregulare & $\mathrm{S}$ & 60 & $2.0 \pm 2.0$ & $1.0 \pm 1.7$ & $1.0 \pm 1.7$ & $0.0 \pm 0.0$ \\
\hline $81774-98$ & irregulare & $\mathrm{S}$ & 70 & $5.0 \pm 0.0$ & $1.8 \pm 1.0$ & $0.5 \pm 1.0$ & $0.0 \pm 0.0$ \\
\hline $81885-99$ & irregulare & $\mathrm{S}$ & 50 & $3.3 \pm 2.9(3)$ & $1.3 \pm 2.3$ & $0.0 \pm 0.0$ & $0.0 \pm 0.0$ \\
\hline P91 & irregulare & $\mathrm{R}$ & 50 & $5.0 \pm 0.0$ & $2.3 \pm 2.1$ & $5.0 \pm 0.0$ & $2.5 \pm 2.9$ \\
\hline $\mathrm{P} 73^{\mathrm{h}}$ & irregulare & $\mathrm{S}$ & 40 & $4.8 \pm 0.4(5)$ & $2.4 \pm 2.1$ & $0.4 \pm 0.9$ & $0.2 \pm 0.4$ \\
\hline $\mathrm{P} 75^{\mathrm{h}}$ & irregulare & $\mathrm{R}$ & 30 & $5.0 \pm 0.0$ & $3.2 \pm 2.0$ & $4.8 \pm 0.4$ & $3.6 \pm 1.7$ \\
\hline P69 & splendens & $\mathrm{R}$ & 60 & $0.0 \pm 0.0$ & $0.0 \pm 0.0$ & $0.0 \pm 0.0$ & $0.0 \pm 0.0$ \\
\hline P28 & ultimum & $\mathrm{S}$ & 71 & $4.2 \pm 1.8(5)$ & $1.6 \pm 1.1$ & $0.0 \pm 0.0$ & $0.2 \pm 0.4$ \\
\hline $31036-96$ & ultimum & $\mathrm{S}$ & 60 & $5.0 \pm 0.0$ & $2.7 \pm 2.3$ & $0.0 \pm 0.0$ & $0.0 \pm 0.0$ \\
\hline P74 & ultimum & $\mathrm{S}$ & 60 & $3.0 \pm 2.4(4)$ & $0.0 \pm 0.0$ & $1.0 \pm 2.0$ & $0.0 \pm 0.0$ \\
\hline P88 & ultimum & $\mathrm{R}$ & 50 & $5.0 \pm 0.0$ & $5.0 \pm 0.0$ & $5.0 \pm 0.0$ & $5.0 \pm 0.0$ \\
\hline P90 & ultimum & $\mathrm{S}$ & 60 & $3.5 \pm 0.6$ & $0.0 \pm 0.0$ & $0.0 \pm 0.0$ & $0.3 \pm 0.5$ \\
\hline P70 & ultimum & $\mathrm{S}$ & 60 & $5.0 \pm 0.0$ & $1.5 \pm 1.7$ & $0.0 \pm 0.0$ & $0.0 \pm 0.0$ \\
\hline $\mathrm{P} 17^{\mathrm{h}}$ & ultimum & $\mathrm{S}$ & 22 & $5.0 \pm 0.0$ & $0.0 \pm 0.0$ & $0.0 \pm 0.0$ & $0.0 \pm 0.0$ \\
\hline $\mathrm{P} 19^{\mathrm{h}}$ & ultimum & $\mathrm{S}$ & 25 & $3.7 \pm 2.0(6)$ & $2.7 \pm 1.9$ & $0.2 \pm 0.4$ & $0.3 \pm 0.5$ \\
\hline
\end{tabular}

a Five Pelargonium $\times$ hortorum cv. 'White Orbit' geranium seeds germinated on filter paper moistened with 20 ml of water-soluble fertilizer ( $\mathrm{N}$ at 400 $\mu \mathrm{g} / \mathrm{ml}, 20 \% \mathrm{~N}, 20 \% \mathrm{P}_{2} \mathrm{O}_{5}, 20 \% \mathrm{~K}_{2} \mathrm{O}$ ) and inoculated by inverting a 10-mm-diameter plug of colonized potato dextrose agar onto the root of each seedling; $\mathrm{SD}=$ standard deviation of error.

${ }^{\mathrm{b}}$ Mefenoxam sensitivity; resistant $(\mathrm{R})=$ growth inhibited by $50 \%\left(\mathrm{EC}_{50}\right)$ for mefenoxam at $>100 \mu \mathrm{g} / \mathrm{ml}$ in corn meal agar, as previously reported (5); sensitive $(\mathrm{S})=\mathrm{EC}_{50}<100 \mu \mathrm{g} / \mathrm{ml}$.

${ }^{\mathrm{c}}$ Percent growth on propamocarb at $1,000 \mu \mathrm{g} / \mathrm{ml}$ compared with growth on 0 fungicide.

${ }^{\mathrm{d}}$ No fungicide; $\mathrm{N}=$ number of times isolate was tested in vivo.

e Seedlings treated with propamocarb (Banol at $2.35 \mu \mathrm{l} / \mathrm{ml}$ in water soluble fertilizer; $\mathrm{N}$ at $400 \mu \mathrm{g} / \mathrm{ml}, 20 \% \mathrm{~N}, 20 \% \mathrm{P}_{2} \mathrm{O}_{5}, 20 \% \mathrm{~K}_{2} \mathrm{O}$ ), equivalent to the labelrecommended $3 \mathrm{fl}$. oz./10 gal concentration.

${ }^{f}$ Seedlings treated with mefenoxam (Subdue Maxx at $0.078 \mu \mathrm{l} / \mathrm{ml}$ in water-soluble fertilizer; $\mathrm{N}$ at $400 \mu \mathrm{g} / \mathrm{ml} \mathrm{20 \%} \mathrm{N,} 20 \% \mathrm{P}_{2} \mathrm{O}_{5}, 20 \% \mathrm{~K}_{2} \mathrm{O}$ ), equivalent to the label-recommended rate of $1 \mathrm{fl}$. oz./100 gal concentration.

$\mathrm{g}$ Seedlings treated with a mixture of propamocarb and mefenoxam.

${ }^{\mathrm{h}}$ Isolate with $\mathrm{EC}_{50}$ for propamocarb at $<1,000 \mu \mathrm{g} / \mathrm{ml}$ included for comparison with those with $\mathrm{EC}_{50} \mathrm{~s}>1,000 \mu \mathrm{g} / \mathrm{ml}$. 
has occurred or whether an insufficient number of isolates were examined in the early studies to detect all the natural variation in sensitivity.

Growth of an organism on agar containing a high concentration of fungicide does not necessarily indicate that the isolate can overcome and kill plants treated with the label-recommended concentration of the chemical. In the present work, isolate $\mathrm{P} 80$, whose in vitro $\mathrm{EC}_{50}$ for propamocarb exceeded $1,000 \mu \mathrm{g} / \mathrm{ml}$, and P16 and P88, with $\mathrm{EC}_{50}$ s close to 1,000 $\mu \mathrm{g} / \mathrm{ml}$, consistently infected most of the propamocarb-treated seedlings and should be deemed propamocarb resistant. However, other isolates with $\mathrm{EC}_{50} \mathrm{~s}$ greater than 1,000 $\mu \mathrm{g} / \mathrm{ml}$ (66011-99, P77, and 81192-96) did not consistently overcome the challenge of the fungicide in vivo. Therefore, the in vitro sensitivity to propamocarb is not a good indicator of in vivo propamocarb resistance. Although many isolates tested here are not considered to be resistant to propamocarb, because they did not consistently infect a majority of the treated seedlings, they did often infect one or two of the five inoculated plants in each test.

Fourteen isolates examined in this study previously have been shown to be resistant to mefenoxam (5). Two of these isolates exhibited in vivo resistance to both propamocarb and mefenoxam. Others using in vivo testing have reported that metalaxyl resistance, an analog of mefenoxam, and propamocarb resistance are genetically independent (7). This is the first report of Pythium spp. with resistance to propamocarb and dual resistance to propamocarb (carbamate) and mefenoxam (acylanilide). Mefenoxam and metalaxyl have been, and continue to be, used extensively in greenhouse crop production. Propamocarb has been used by the turf industry in Pennsylvania for Pythium spp. management but has not been employed extensively by greenhouse operators (G. W. Moorman, unpublished survey). Finding in vivo propamocarb resistance in three different species of Pythium from greenhouse samples was unexpected. Its occurrence may be an indication of the natural variation in sensitivity to propamocarb in species of Pythium rather than a result of selection pressure resulting from the use of the fungicide. It also is possible that these isolates originated in locations exposed to propamocarb and then were introduced into the greenhouse production area via contaminated soil or on infected plants. The detection of propamocarb resistance coupled with the previous finding that almost $40 \%$ of the P. aphanidermatum and $P$. irregulare isolates have resistance to mefenoxam (5) indicates that the options growers have for chemical control of $P y$ thium spp. may be fewer than previously assumed.

In the greenhouse industry, it is not unusual for growers to unknowingly purchase Pythium spp.-infected potted plants, cuttings, and seedlings from other operations. By this process, fungicide-resistant pathogens can be moved geographically within the industry. It may be necessary to routinely determine the level of fungicide sensitivity in isolates of Pythium obtained in clinic samples prior to formulating chemical control recommendations, regardless of whether or not the grower submitting the sample has used a particular fungicide. Routine testing will be difficult in the case of propamocarb because in vivo resistance cannot be predicted from a simple in vitro test. The seedling test used here revealed a great deal of variation in pathogenicity among isolates. An isolate should be tested at least twice, inoculating 10 or more seedlings per test. A more rapid and efficient method of testing for propamocarb resistance is needed.

\section{ACKNOWLEDGMENTS}

We thank N. Arora for initially finding propamocarb resistant isolates and for his technical assistance in developing the in vivo test. We thank the American Floral Endowment, the Floriculture and Nursery Crops Research Initiative, and the Gloeckner Foundation for the funding that supported this work.

\section{LITERATURE CITED}

1. Cohen, Y., and Coffey, M. D. 1986. Systemic fungicides and the control of Oomycetes. Annu. Rev. Phytopathol. 24:311-338.

2. Farr, D. F., Bills, G. F., Chamuris, G. P., and Rossman, A. Y. 1989. Fungi on Plants and Plant Products in the United States. American Phytopathological Society Press, St. Paul, MN.

3. Hendrix, F. F., and Campbell, W. A. 1973. Pythiums as plant pathogens. Annu. Rev. Phytopathol. 11:77-98.

4. Middleton, J. T. 1943. The taxonomy, host range and geographic distribution of the genus Pythium. Mem. Torrey Bot. Club 20:1-171.

5. Moorman, G. W., Kang, S., Geiser, D. M., and Kim, S. H. 2002. Identification and characterization of Pythium species associated with greenhouse floral crops in Pennsylvania. Plant Dis. 86:1227-1231.

6. Papavizas, G. C., O'Neill, N. R., and Lewis, J. A. 1978. Fungistatic activity of propyl-N-[adimethylaminopropyl) carbamate on Pythium spp. and its reversal by sterols. Phytopathology 68:1667-1671.

7. Samoucha, Y., and Cohen, Y. 1990. Toxicity of propamocarb to the late blight fungus on potato. Phytoparasitica 18:27-40.

8. Sanders, P. L. 1984. Failure of metalaxyl to control Pythium blight on turfgrass in Pennsylvania. Plant Dis. 68:776-777.

9. Taylor, R. J., Salas, B., Secor, G. A., Rivera, V., and Gudmestad, N. C. 2002. Sensitivity of North American isolates of Phytophthora erythroseptica and Pythium ultimum to mefenoxam (metalaxyl). Plant Dis. 86:797-802.

10. Thomson, W. T. 1997. Agricultural Chemicals Book IV: Fungicides. 12th ed. Thomson Publications. Fresno, CA.

11. van der Plaats-Niterink, A. J. 1981. Monograph of the genus Pythium. Studies in Mycology, Vol. 21. Centraalbureau Voor Schimmelcultures, Baarn, The Netherlands. 